\title{
近赤外域の単一波長を利用した 中和反応で生成する塩濃度の可視化
}

\author{
川嶋 大介 1 ), 角田 直人 ${ }^{2)}$, 有本 英伸 3) 近藤 克哉 ${ }^{4)}$, 山田 幸生 ${ }^{5)}$
}

\section{Visualization of Concentrations of Salts Produced during Neutralization}

\section{Reactions by using Single Wavelength in the Near-infrared Region}

\begin{abstract}
This paper proposes a novel imaging method using near infrared light of single wavelength to visualize the concentration distribution of salt generated by neutralization reaction of aqueous solutions of acid and alkali in a microfluidic channel. This method is based on the absorption characteristics of the aqueous solutions at the wavelength of $1520 \mathrm{~nm}$ in the $v_{1}+v_{3}$ absorption band of water. The wavelength of $1520 \mathrm{~nm}$ is an isosbestic point for the aqueous solutions of the acid and alkali with respect to their concentrations while the absorbance of the salt solutions at $1520 \mathrm{~nm}$ vary with their salt concentrations. To verify the proposed single-wavelength imaging method, the concentration images of sodium chloride $(\mathrm{NaCl})$ were obtained and analyzed in two cases of the combinations of two liquids flowing into a T-shaped microchannel: (i) water and aqueous solution of $\mathrm{NaCl}$, and (ii) hydrochloric acid and sodium hydroxide. The measured concentrations of $\mathrm{NaCl}$ agreed well with the expected distributions of the concentrations and verified the proposed method.
\end{abstract}

Daisuke Kawashima, Naoto Kakuta, Hidenobu Arimoto, Katsuya Kondo and Yukio Yamada

Keywords : Visualization, Concentration, Near-infrared, Water, Neutralization reaction, Salt, Absorption

\section{1. はじめに}

近年, マイクロ流路を有した分析・反応デバイスが数多く 考案されており，化学・生化学分野や創薬分野への応用が期 待されている ${ }^{1-3)}$. マイクロ流路を利用するメリットとして, 装置の小型化, 試料量の低減, 加熱冷却時間の短縮などがあ げられるが, 加えて, 流路構造の工夫により試料の拡散混合・ 反応・分離過程を段階的に計測制御できることも大きな利点 である ${ }^{4)}$ 。これらの混合反応系の計測制御では, 試料溶液の 各物質濃度, とりわけ反応後の生成物濃度が重要であるため, 特定の生成物濃度を選択的に測定できる技術が求められて きた。

* 原稿受付 2016 年 7 月 3 日

1) 学生員 首都大学東京大学院 理工学研究科 (下192-0397 東京 都八王子市南大沢 1-1, E-mail : kawashimadaisuke@ed.tmu.ac.jp)

2) 正会員 首都大学東京大学院 理工学研究科

3）産業技術総合研究所 電子光技術研究部門

4) 鳥取大学大学院 工学研究科

5）電気通信大学 脳科学ライフサポート研究センター
マイクロ流路内の物質濃度測定には, これまで, 蛍光物質 を利用した手法が数多く提案されてきた ${ }^{5)}$. その中でも特に, レーザー誘起蛍光法（LIF 法）が精力的に研究され，物質濃 度のみならず, 温度 ${ }^{6}$ や $\mathrm{pH}^{7}$ )の測定にも利用されてきた。ま た, LIF 法では蛍光以外の影響を極力排除して高精度な測定 を実現するため，2 波長を用いる場合も多い（2 色 LIF 法) 8)。さらに，LIF 法と粒子イメージ流速法（PIV 法）を組み合 わせた $\mathrm{pH}$ と速度場の同時計測手法も考案されている ${ }^{9)}$. し かし, 実際の化学分析や合成では蛍光物質のような異物の混 入は純度の点から許されない場合が多い. 加えて, 蛍光物質 の存在が拡散反応場に影響を与えている可能性もあるため, 蛍光物質を使用しない可視化手法が望まれてきた。一例とし て, 密度差を利用するマッハツェンダー干渉計を応用した方 法 ${ }^{10)}$ があるが，複数種の物質が混在する場合の測定は極め て難しい.また，ラマン分光法が近年盛んに研究されており 11), 最近では空間走査を必要としないコヒーレントアンチス トークスラマン散乱を利用したイオン濃度計測も考案され ている ${ }^{12)}$.

本論文で提案する計測法は, 水溶液の近赤外吸収分光特性 
に基づいて決定された単一波長を用いる方法である.近赤外 分光法は, ラマン分光法と同様に, PDMS やガラスなどのセ ル内部の試料の測定に有利であるが, ラマン分光法と異なる 点は, 光源の制約がなく, 光学システムも簡素化しやすいた め, 簡便で低コストの測定システムを実現できることである. また, 近赤外スペクトルは溶媒である水とイオンの相互作用 による水和構造の変化を反映するため, イオンや溶質単体の 濃度のみならず, 温度, 圧力, 粘性などの情報も取得するこ とができる ${ }^{13)}$. そのため, 近赤外分光法は様々な分野で広く 用いられてきたが, 最近では, ハイパースペクトラルイメー ジングと呼ばれるイメージ分光技術の開発も盛んである ${ }^{14)}$. しかし,ハイパースペクトラルイメージング技術の多くは空 間走查型ゆえに過渡的な現象を捉えることは難しい.これに 対して本手法は, 単一波長の吸収画像を近赤外カメラによっ て取得する従来型の方法ではあるが, 測定システムの簡素化 と高速なイメージングが実現でき, 拡散・反応過程の時間分 解測定に適している.

一般に, 近赤外域における吸収バンドは, 中赤外域の吸収 バンドと比較してブロードで強度も小さいため, マイクロ流 路内水溶液の溶質濃度を直接測定することは困難な場合が 多い. 加えて, 水の吸収バンドが圧倒的に大きく支配的であ るため, 溶質固有の吸収バンドが埋もれてしまう場合も多い. 逆に, 著者らはこの水の吸収バンドの大きさに着目し, マイ クロ流路のように光路長が小さい場合は, 水の吸収バンドの 測定が溶質濃度の推定に有効であることを示してきた ${ }^{15)}$. そして, 各種水溶液のスペクトル分析を通じて, 各濃度に対 して高感度な波長や, 感度がない波長 (等吸収点)を見出し, 各波長の組み合わせもしくは単独に利用したイメージング の可能性を探ってきた ${ }^{16-20)}$.

本論文は, 水溶液の代表的な反応のひとつである酸・アル カリ中和反応に着目し, そこで生成される塩濃度を波長 $1520 \mathrm{~nm}$ を用いてイメージングすることを目的としている. 波長 $1520 \mathrm{~nm}$ は, 酸・アルカリ・塩の濃度に対する水の $v_{1}$ $+v_{3}$ 吸収バンドの変化特性に基づき決定されたものであり, 著者らの知る限り, 濃度測定に用いられた例はない。単一波 長を用いる利点は先に述べたとおりであるが, 一方で濃度以
外の変動成分の影響が懸念される. そのため, 著者らは同じ く中和反応に対して複数波長によるイメージングを試みて きたが 16-19), マイクロ流路のように流路形状や光路が変化 しない場合は，それらの影響は十分小さいことを実証し，単 一波長による本イメージング法の提案に至った. 塩濃度の計 測は, 中和反応以外にもシリコンウェハーのエッチングやソ ーダ工業で精製される水酸化ナトリウム中に存在する $\mathrm{NaCl}$ などの不純物の検出や, 淡水化研究の分野において必要不可 久である. 提案する方法の現状ではこれらの用途に対する精 度等の具体的な検証はしていないが, 将来, これらのインラ イン測定や画像分析などに活用されることも期待される.

本論文では, はじめに, 酸・アルカリ・塩の水溶液の近赤 外吸収スペクトルを示し, 各濃度に対する変化特性を明らか にするとともに塩濃度の可視化手法を解説する. 次に, 本手 法の有効性を評価するため, $\mathrm{T}$ 字型マイクロ流路内で水と塩 水溶液を接触させ, 拡散による濃度変化を可視化する. 最後 に, 酸・アルカリ水溶液の反応場における塩濃度測定を行い, 結果について考察する.

\section{2. 酸·アルカリ·塩の近赤外吸収スペクトル}

塩酸 $\mathrm{HCl}(\mathrm{aq})$, 硫酸 $\mathrm{H}_{2} \mathrm{SO}_{4}(\mathrm{aq})$, 水酸化ナトリウム水溶液 $\mathrm{NaOH}(\mathrm{aq})$, 水酸化カリウム水溶液 $\mathrm{KOH}(\mathrm{aq})$, およびそれら の生成塩水溶液である塩化ナトリウム水溶液 $\mathrm{NaCl}(\mathrm{aq})$ と塩 化カリウム水溶液 $\mathrm{KCl}(\mathrm{aq})$ の近赤外吸収スペクトルを測定 した。 以下では水溶液についてのみ言及するため, (aq) は省 略する。濃度は, すべての水溶液で $0.2,0.5,1.0,2.0 \mathrm{M}(\mathrm{mol} / \mathrm{L})$ とした. なお, 上記の酸・アルカリの組み合わせによる塩と しては $\mathrm{K}_{2} \mathrm{SO}_{4}$ と $\mathrm{Na}_{2} \mathrm{SO}_{4}$ もあるが，水への溶解度が小さいた め今回は対象外とした. 試料溶液は光路長 $1.0 \mathrm{~mm}$ の石英セ ルに封入し, 測定には FT-IR 分光光度 (IR Prestage-21, SHIMADZU, Japan）を使用した。試料温度は, FT-IR 試料室 に搭載された温度制御装置（110-6015, PIKE Technology, USA) を用いて, $20.0 \pm 0.1^{\circ} \mathrm{C}$ に調整した. Fig. 1 に, 波長範囲 1250 $1650 \mathrm{~nm}$ における $\mathrm{HCl}, \mathrm{NaOH}, \mathrm{NaCl}$ の吸収スペクトルを示 す. 吸光度 $A$ は, 次式から算出した。
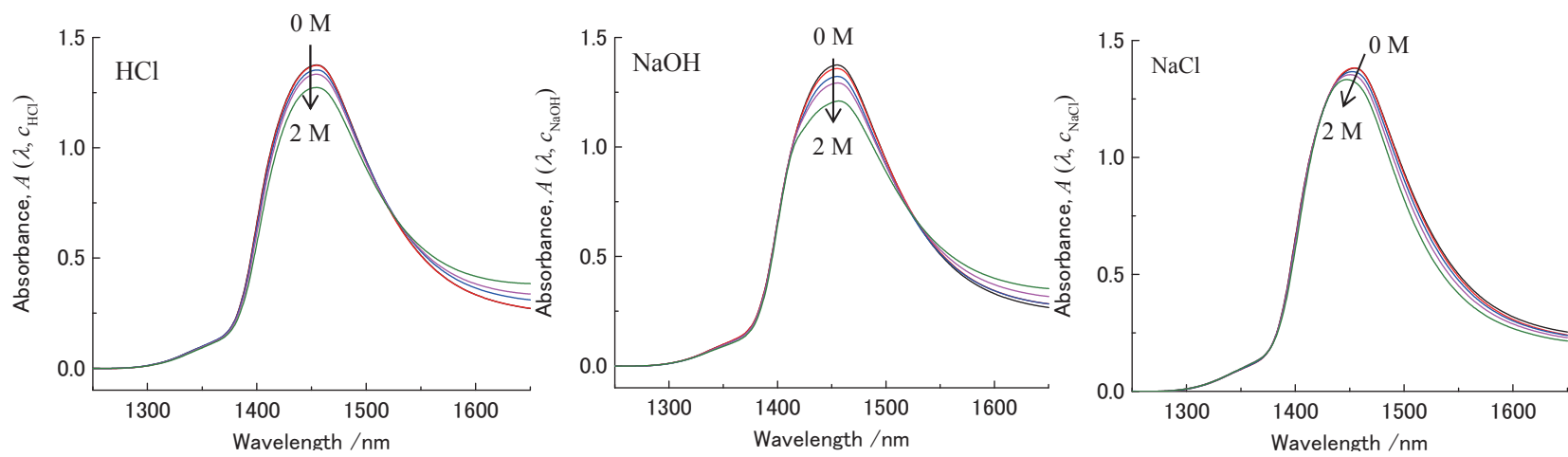

Fig. 1 Absorbance spectra of aqueous solutions of $\mathrm{HCl}$ (left), $\mathrm{NaOH}$ (center), and $\mathrm{NaCl}$ (right) with the concentrations of $0,0.2,0.5,1.0$, and $2.0 \mathrm{M}$ at the temperature of $20^{\circ} \mathrm{C}$. 


$$
A\left(\lambda, c_{1}, c_{2}, \cdots\right)=-\log _{10} \frac{I\left(\lambda, c_{1}, c_{2}, \cdots\right)}{I_{0}(\lambda)}
$$

ここで, $I_{0}$ は入射光強度, $I$ は透過光強度, $c_{\mathrm{i}}$ は溶質成分 $\mathrm{i}$ のモル濃度を表す. $I_{0}$ は照射光強度であるが,ここでは空の 石英セルの透過光強度を用いた. 尚, 他の水溶液のスペクト ルについては同様の傾向を示したため省略した。

Fig. 1 では, す心゙ての水溶液において, 波長 $1450 \mathrm{~nm}$ をピ 一クとした水の $v_{1}+v_{3}$ 吸収バンドが観察される.この吸収バ ンドは水分子の $\mathrm{OH}$ 結合の対称および逆対称伸縮振動の結 合音に対応する ${ }^{211}$. これらの吸収スペクトルの顕著な違い

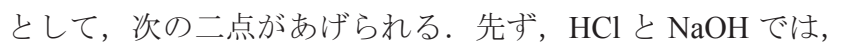
波長 $1520 \mathrm{~nm}$ において $A$ が濃度によらず一定となる等吸収 点が存在するが， $\mathrm{NaCl}$ では観察されないことである。これ については吸光度差スペクトルでより明膫に確認されるた め, 後述する.もう一点は, 濃度上昇とともに, $\mathrm{HCl}$ と $\mathrm{NaOH}$ ではピーク付近の $A$ が全体的に減少するのに対して, $\mathrm{NaCl}$ では減少に加えてピークが短波長側にシフト寸ることであ る. この変化の違いは, 水素結合状態と密接に関係寸る. 水 の吸収バンドは, 複数の水素結合種に帰属されるサブバンド のコンボリューションと解採され ${ }^{22,23)}$, その中で水素結合 のない自由水に帰属されるサブバンドが, 短波長側 (1400 nm 付近）に存在する ${ }^{24)}$. つまり, $\mathrm{NaCl}$ 濃度の増加によって吸 収バンドが短波長シフトした原因は, 自由水の割合が相対的
に増加したことと考えられる. $\mathrm{NaCl}$ が水溶媒中に溶け込む と $\mathrm{Na}^{+}$や $\mathrm{Cl}^{-}$は水分子と相互作用し, これらのイオンの周辺 に水和を形成するが，さらに，そのまわりには自由水の領域 が存在すると考えられている ${ }^{25}$. イオン半径の大きなイオ ンとなる $\mathrm{NaCl}$ の場合には, 水分子との相互作用が弱いため, $\mathrm{NaCl}$ 濃度上昇によって自由水の領域が相対的に拡大し, 短 波長シフトを引き起こしたと解棌できる.

Fig. 2 に, $20^{\circ} \mathrm{C}$ の純水の吸光度を基準とした各水溶液の 吸光度差スペクトルを示す. 吸光度差 $\Delta A$ は次式により算出 される。

$$
\Delta A=A-A_{\mathrm{r}}=-\log _{10} \frac{I}{I_{0}}-\left(-\log _{10} \frac{I_{\mathrm{r}}}{I_{0}}\right)=-\log _{10} \frac{I}{I_{\mathrm{r}}}
$$

ここで, $A_{\mathrm{r}}$ は基準吸光度, $I_{\mathrm{r}}$ は基準透過光強度である. 波長 範囲 1200-1520 nm ではすべての試料で濃度上昇にともなっ て $\triangle A$ が減少する。一方，1520-1600 nm では，酸・アルカリ 水溶液については $\Delta A$ が増加し, 波長 $1520 \mathrm{~nm}$ が等吸収点と なる.この等吸収点は, $\mathrm{H}^{+} や \mathrm{OH}^{-}$の存在に起因する。これら のイオンは, $\mathrm{NaCl}$ 同様, 水分子間の水素結合に影響を与え るが，イオン自体も水分子との水素結合を形成するため, $\mathrm{NaCl}$ や $\mathrm{KCl}$ とは異なるスペクトル変化を生じたと考えられ る. $\mathrm{NaCl}$ と $\mathrm{KCl}$ の塩水溶液については, 波長 $1520 \mathrm{~nm}$ では $\triangle A$ は塩濃度と共に減少する。

以上の事実は, 波長 $1520 \mathrm{~nm} の \Delta A$ を測定することで, 酸・
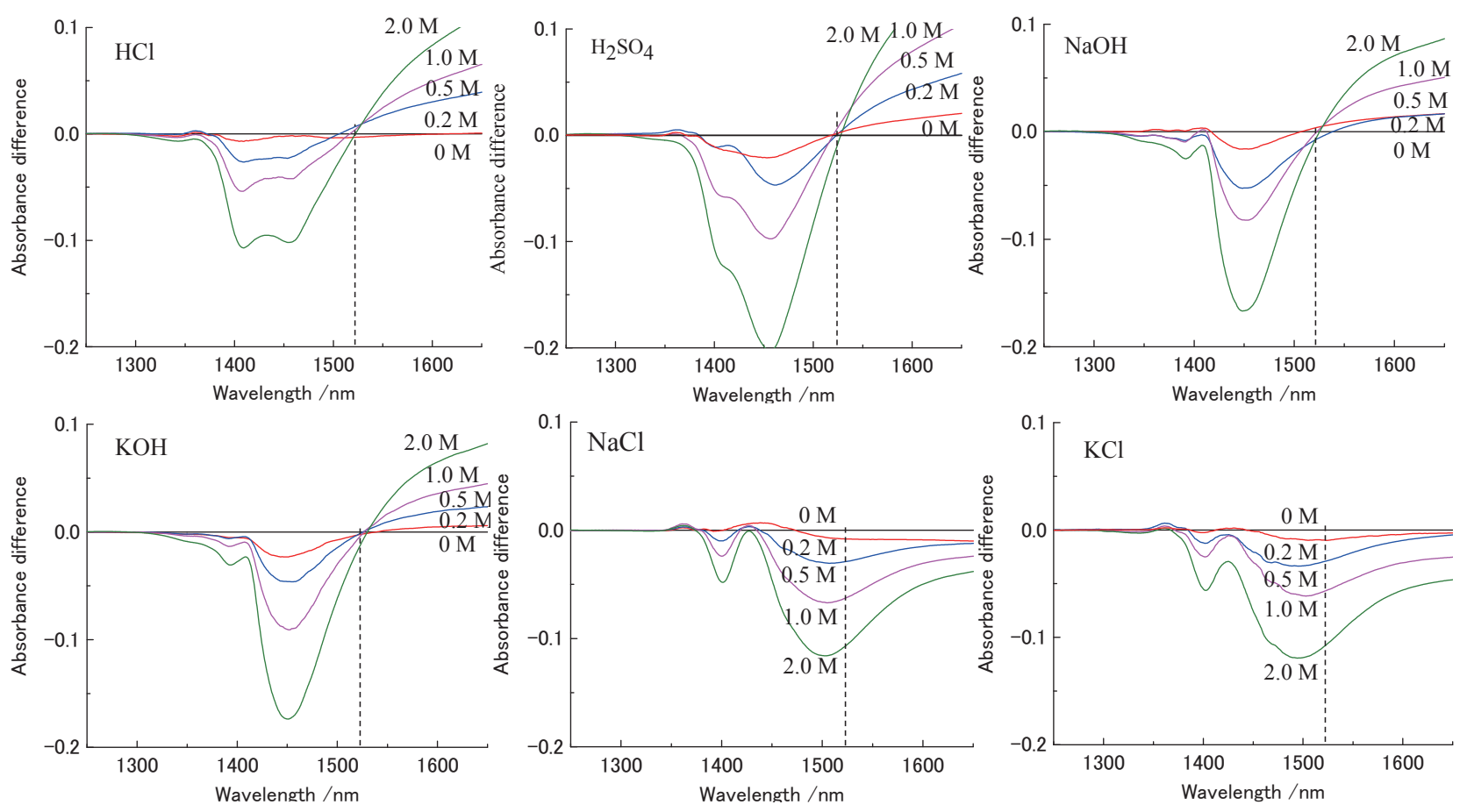

Fig. 2 Absorbance difference spectra of aqueous solutions of acid $\left(\mathrm{HCl}, \mathrm{H}_{2} \mathrm{SO}_{4}\right)$, alkali $(\mathrm{NaOH}, \mathrm{KOH})$, and salt $(\mathrm{NaCl}, \mathrm{KCl})$ with the concentrations of $0.2,0.5,1.0$, and $2.0 \mathrm{M}$ at the temperature of $20^{\circ} \mathrm{C}$. The reference is the absorbance of pure water $(0 \mathrm{M})$. The vertical dashed line in each graph indicates the wavelength of $1520 \mathrm{~nm}$. 


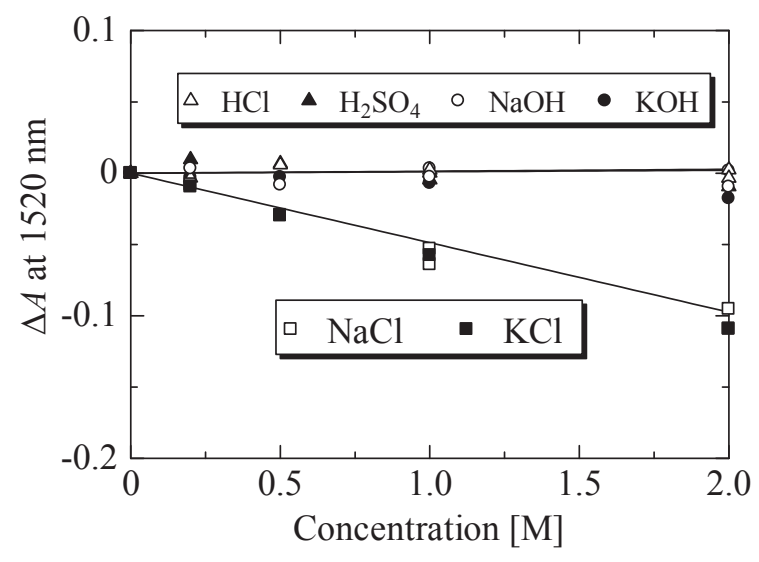

Fig. 3 Absorbance difference, $\Delta A$, of acid $\left(\mathrm{HCl}, \mathrm{H}_{2} \mathrm{SO}_{4}\right)$, alkali $(\mathrm{NaOH}, \mathrm{KOH})$, and salt $(\mathrm{NaCl}, \mathrm{KCl})$ at the wavelength of $1520 \mathrm{~nm}$ as functions of their concentrations. The optical path length is 1.0 $\mathrm{mm}$.

アルカリの濃度変化の影響を受けずに, 塩濃度のみを選択的 に定量できることを意味する. Fig. 3 は各水溶液の濃度と波 長 $1520 \mathrm{~nm}$ のA の関係である. 酸・アルカリでは濃度依存 性がなく, 塩に関しては良好な線形関係 $\left(-4.59 \times 10^{-2} \mathrm{M}^{-1}\right)$ があることが分かる. なお, 分光測定で得られる光強度およ び波長の誤差と, 等吸収点が濃度範囲によって異なること 26, 27)を考慮すれば, 厳密には, Fig. 2 の $\mathrm{HCl}, \mathrm{H}_{2} \mathrm{SO}_{4}, \mathrm{NaOH}$ およ び $\mathrm{KOH}$ の等吸収点は 1520-1525 nm の範囲に存在すると述 ベるのが適切かもしれない. しかし実際には, 使用する狭帯 域透過フィルタの半值幅によって $\Delta A$ は平均化されることも あり,この波長範囲内に透過ピークがあるフィルタを選択す れば, $1520 \mathrm{~nm}$ からの差は十分無視でき, 測定精度上の問題 はほとんどない.

塩と酸・アルカリが共存している場合, 例えば $\mathrm{pH}$ 調整さ れた $\mathrm{NaCl}$ と $\mathrm{HCl}$ の混合水溶液の場合, $\mathrm{Cl}^{-}$が共通している ものの, $\mathrm{HCl}$ 由来の $\mathrm{Cl}^{-}$の影響は排除され, $\mathrm{NaCl}$ の濃度のみ を選択的に測定することができる。これは, 近赤外吸収スペ クトルには, イオン種ではなく, その水和構造すなわち塩と しての吸収特性が反映されるためである. よって, 中和反応 過程でも塩濃度を選択的に测定できる.ただし, $\mathrm{NaCl}$ と $\mathrm{KCl}$ など複数の塩が混在する場合は, 混合塩としての濃度が検出 される.

吸収スペクトルは温度によっても変化するため ${ }^{21)}$, 反応 熱による影響を受ける可能性がある。例えば, $\mathrm{HCl}+\mathrm{NaOH}$ $\rightarrow \mathrm{NaCl}+\mathrm{H}_{2} \mathrm{O}$ の中和熱は $56.5 \mathrm{~kJ} / \mathrm{mol}$ であり, 断熱状態で 1 $\mathrm{mol}$ が完全反応した場合, 温度上昇は約 $6{ }^{\circ} \mathrm{C}$ とな. しか し, マイクロ流路の場合, 大きな比表面積ゆえに溶液から周 囲への熱損失が大きく, さらに反応は溶液間界面の局所的な ものであることから, 反応熱による実際の温度変化は非常に 小さい, なお, 波長 $1520 \mathrm{~nm}$ では, 温度変化 $+1{ }^{\circ} \mathrm{C}$ は濃度変 化-0.075 M の濃度変化に相当する.

\section{3. 塩濃度のイメージング方法}

塩濃度のイメージングには，著者らがこれまでに開発し た装置 16-19)の光学フィルタを変更した装置を用いた。 八ロ ゲンランプからの光を中心波長 $1520 \mathrm{~nm}$, 半值全幅 $10 \mathrm{~nm}$ の 狭帯域透過フィルタ (NBPF)を通して試料に照射した。尚, 比較のため, 中心波長 $1442 \mathrm{~nm}$, 半值全幅 $10 \mathrm{~nm}$ の NBPF を 交換して使用した ${ }^{15)}$. これは, Fig. 2 で示されるように, 波 長 $1442 \mathrm{~nm}$ の $A$ は塩濃度に対する変化が小さく, 酸・アル カリに対しては大きく変化するため, 波長 $1520 \mathrm{~nm}$ の画像 とは対照的に, 塩濃度によらない画像が得られる. そのため 濃度以外の要因, 例えば屈折率変化などの影響を確認できる ことから $1442 \mathrm{~nm}$ の画像を取得し比較した. 試料は, 顕微鏡 (BX-51, Olympus, Japan) のステージ上に置かれ，2 次元透 過光画像を近赤外カメラ (CV-N800, Sumitomo Electric Industries, Japan）によって取得した. カメラ素子は $320 \times 256$ pixels $の \mathrm{InGaAs}$ 素子, 出力データは $16 \mathrm{bit}$, フレームレート は320 fps (max)である.

今回の実験では, $\mathrm{T}$ 字型の流路を用いて, 2 つの異なる水 溶液をそれぞれ枝流路から流して主流路で合流させた。 Fig. 4 に示すように，2枚の石英ガラス板の間に，主流路（幅 2.0 $\mathrm{mm}$ ) と枝流路（幅 $1.5 \mathrm{~mm}$ ) からなる $\mathrm{T}$ 字に型取った厚さ 0.2 $\mathrm{mm}$ のシリコーンシートを挟むことで流路を形成した。試料 の組み合わせは以下の 2 種類を設定した: (i) 純水と濃度 1.0 $\mathrm{M}$ または $2.0 \mathrm{M}$ の $\mathrm{NaCl}$ ，(ii) 等濃度 $(0.5,1.0,2.0 \mathrm{M})$ の $\mathrm{HCl}$ と $\mathrm{NaOH}$. (i) は 2 液の拡散混合, (ii) は中和反応時の濃度測定 を目的としている.流れはシリンジポンプの吸引モードによ って生じさせ, 流量は $80 \mu \mathrm{L} / \mathrm{hr}$ (流速 $0.055 \mathrm{~mm} / \mathrm{s}$ ) とした.

取得した透過光画像は, $3 \times 3$ pixel 平均で平滑化を行い, 式(2)にしたがって $\Delta A$ 画像を得た。基準となる $I_{\mathrm{r}}$ 画像には, 流路を純水で満たした状態での透過光画像を用いた。 $\Delta A$ は

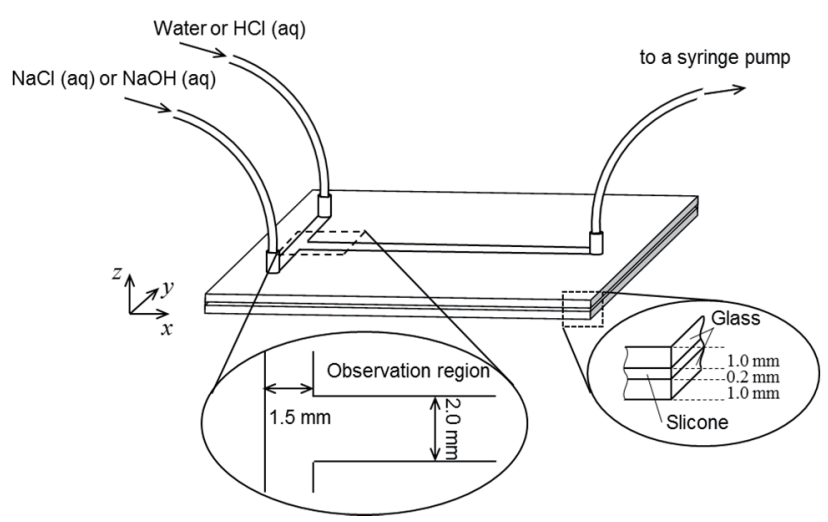

Fig. 4 Schematics of the T-shaped microfluidic chip made of two glass plates and a sandwiched silicone plate with a T-shape cutout. The width of the main channel is $2.0 \mathrm{~mm}$ and that of the branch channels is $1.5 \mathrm{~mm}$. The depth of the channel is $0.2 \mathrm{~mm}$. 
次式によって $\mathrm{NaCl}$ 濃度 $\left(c_{\mathrm{NaCl}}\right)$ の変化量に変換される.

$$
\Delta c_{\mathrm{NaCl}}=\frac{\Delta A(1520 \mathrm{~nm})}{\alpha d}
$$

ここで, $d$ は光路長 $(\mathrm{mm}), \alpha$ は吸収係数 $(\Delta A / d)$ の濃度に 対する変化率 $\left(\mathrm{M}^{-1} \mathrm{~mm}^{-1}\right)$ であり, 前節の分光測定結果より, $\alpha=-4.38 \times 10^{-2} \mathrm{M}^{-1} \mathrm{~mm}^{-1}$ を得た. 寸なわち， $d$ が既知の試料 に対して, 測定された $\Delta A$ に $1 / \alpha$ を掛けることで濃度を求め ることができる．ただし，この值と NBPFを用いた場合の $\alpha$ の值は若干異なることと, 今回用いた流路の $d$ の不確かさ を考慮して, 実際のイメージング装置と流路を用いた検量実 験を行い, 変換係数として $1 /(\alpha d)=-133.3 \mathrm{M}$ を得た. 本研 究ではこの值を用いて濃度変換した。

なお， $\Delta A$ は $d$ に依存するため, $d$ の大きさが濃度の測定 精度に大きく影響し, 同じ透過光強度が得られるならば, $d$ が小さいほど濃度測定の精度は悪くなる。今回の $d=0.20 \pm$ $0.02 \mathrm{~mm}$ の場合, 測定信号の $\mathrm{S} / \mathrm{N}$ に基づくノイズは測定され る濃度に換算すると $0.06 \mathrm{M}( \pm 0.35 \mathrm{w} / \mathrm{w} \%)$ の誤差に相当す ると見積もられる， $d$ をより大きくできるのであれば，例え ば $d=1.00 \mathrm{~mm}$ の場合, 測定される濃度の誤差は $\pm 0.003 \mathrm{M}( \pm$ $0.017 \mathrm{w} / \mathrm{w} \%)$ となり, 一般的な屈折率計の精度 $(\sim 0.1 \mathrm{w} / \mathrm{w} \%)$ よりも高い精度が得られる，ただし， $d$ を大きくすると同じ 透過光強度を得ることは難しくなるため, 濃度值の測定誤差 は $d$ と透過光強度との兼ね合いで決まる ${ }^{13)}$. より高い精度 を求める場合は, 露光の時間を長くとることでノイズレベル を低減することや, さらに短い光路長 $(d \leq 0.1 \mathrm{~mm})$ の場合に

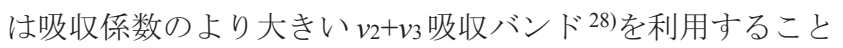
が考えられる.

\section{4. 結果と考察}

\section{1 水-塩水溶液の拡散}

Fig. 5 (a) は, 純水と $\mathrm{NaCl}$ を $\mathrm{T}$ 字型流路に流入させたとき の $\mathrm{NaCl}$ 濃度（以下 $c_{\mathrm{NaCl}}$ ) の画像である. 2 つの流体間で明 瞭な $c_{\mathrm{NaCl}}$ の違いが表れ, 上枝流路からの水の流入部では $c_{\mathrm{NaCl}}$ がほぼ 0 となり, 下枝流路からの $\mathrm{NaCl}$ の流入部の $c_{\mathrm{NaCl}}$ は調 整濃度（1 M, 2 M ）を反映した. 今回, 水の流量が僅かに大 きかったため, 合流部では両溶液の境界面は中央より若干下 側に形成されたが，流れ方向（ $x$ 方向）とともに $\mathrm{NaCl}$ が拡 散によって $y$ 方向に拡がり, 偏りが緩和される様子が観察さ れた. Fig. 5 (b)は $c_{\mathrm{NaCl}}$ の $y$ 方向ラインプロファイルである. ここで, 座標 $x, y$ の原点およびライン位置は Fig. 5 (a) に示 すとおりである.どの条件でも，y=0 mm で $c_{\mathrm{NaCl}}$ が最大と なり, $y$ の増加とともに $c_{\mathrm{NaCl}}$ が単調減少している。 また， $x$ が大きくなるに従って，濃度勾配は全体的に緩やかになり， 拡散の進行も確認できる.

Fig. 5 (b) には, 比較のため, 次の定常二次元拡散方程式
の数值計算結果を示した.

$$
u \frac{\partial c}{\partial x}+v \frac{\partial c}{\partial y}=D\left(\frac{\partial^{2} c}{\partial x^{2}}+\frac{\partial^{2} c}{\partial y^{2}}\right)
$$

ここで, $u, v$ は $x, y$ 方向の速度, $c$ を $\mathrm{NaCl}$ のモル濃度とし， 拡散係数 $D$ には水溶媒中での $\mathrm{NaCl}$ の拡散係数 $\left(1.6 \times 10^{-9}\right.$ $\mathrm{m}^{2} / \mathrm{s}$ at $\left.25{ }^{\circ} \mathrm{C}\right)$ を用いた ${ }^{29)}$. 濃度 $c$ については, 壁面でノイ マン条件 $(\partial c / \partial y=0)$ を与え，流速 $u, v$ には定常二次元非圧 縮流体の数值解を用いた. 計算結果は実験結果と概ね一致し ていることがわかる．このときのペクレ数はおよそ 12 と見 積もられ， $x$ 方向は対流， $y$ 方向は拡散が支配的であり，典 型的なマイクロ流路内の輸送形態となっている. そのため, 特に中央付近 $(y \sim 1.0 \mathrm{~mm})$ においては $y$ 方向勾配の $x$ 方向 の変化が実験結果と一致したことは, 実験で得られた $c_{\mathrm{NaCl}}$ 分 布が $x$ 方向の対流と $y$ 方向の拡散が支配的という点から妥 当であることを示唆している. また，一様流速 $u=u_{0}=\mathrm{const}$ の場合に式(4)の $y$ 方向の対流項（左辺第 2 項）と $x$ 方向の 拡散項（右辺括弧内第 1 項）を無視し， $x=u_{0} t$ として得られ る非定常一次元（ $y$ 方向）拡散の仮定に基づく拡散係数の推 定法 ${ }^{30)}$ を本実験結果に適用すると， $D=1.3 \times 10^{-9} \sim 1.9 \times 10^{-}$ ${ }^{9} \mathrm{~m}^{2} / \mathrm{s}$ と求められ, 上で示した文献值 ${ }^{29)}$ と一致する.

Fig. 5 (c) は，Fig. 5 (a) と同条件で取得した波長 1442 nm の $\triangle A$ 画像である. 尚, 比較のため, Fig. 5 (a)には濃度スケー ルとともに変換前の $\Delta A$ の值を示している．流路内全体で波 長 $1442 \mathrm{~nm}$ の $\Delta A$ は波長 $1520 \mathrm{~nm}$ のそれよりも著しく小さ い.これはFig. 2 の $\mathrm{NaCl}$ と $\mathrm{KCl}$ の差スペクトルに示される ように，塩では波長 $1442 \mathrm{~nm}$ 付近の $\Delta A$ が相対的に非常に小 さいためである。ただし，完全な等吸収点ではないため，濃 度変化により流路下側の $\Delta A$ は若干増加しているが，それ以 外の有意な変化はみられない。すなわち，波長 $1442 \mathrm{~nm}$ と $1520 \mathrm{~nm}$ に共通して現れる液体間の屈折率差のような他の 要因にほとんど影響されていないことが分かる.このことは, 波長 $1520 \mathrm{~nm}$ の $\Delta A$ 画像が $c_{\mathrm{NaCl}}$ のみによって説明されること を示している.

以上より, 水中での $\mathrm{NaCl}$ の拡散現象の可視化および定量 化に関して, 本イメージング法が有効であることを確認した。

\section{2 酸·アルカリ水溶液の反応拡散}

Fig. 6 (a)は，等濃度 $(0.5,1.0,2.0 \mathrm{M})$ の $\mathrm{HCl}$ （流路上側） と $\mathrm{NaOH}$ (下側) を合流させたときの $c_{\mathrm{NaCl}}$ 画像である.また, それぞれの画像に対する濃度ラインプロファイルを Fig. 6 (b)に示した. Fig. 6 (a), (b)より，流れ方向に沿った流路中央 付近 $(y \sim 1.0 \mathrm{~mm})$ において $\mathrm{NaCl}$ が生成し, $y$ の正負両方向 に拡散する様子が確認できる．Fig. 6 (b) のすべてのグラフ に共通して, 流路中央に関して対称的な濃度分布が観察され た. $2.0 \mathrm{M}$ の場合， $x$ 方向によって濃度分布に有意な変化が 


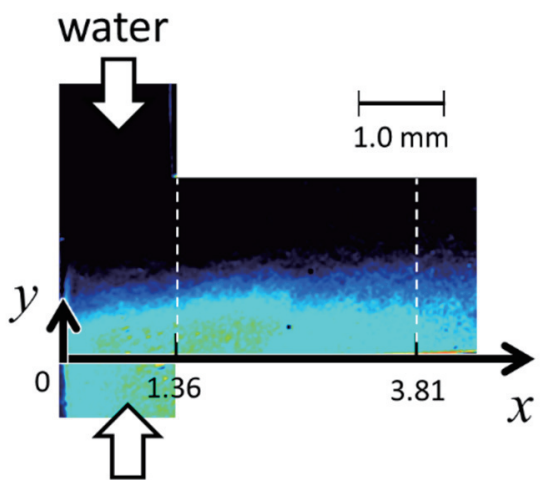

$1.0 \mathrm{M} \mathrm{NaCl}$

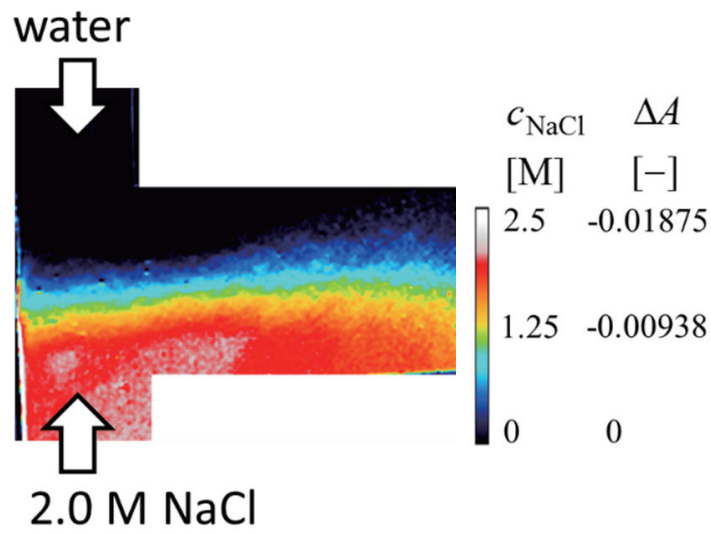

(a) Concentration images of $\mathrm{NaCl}$
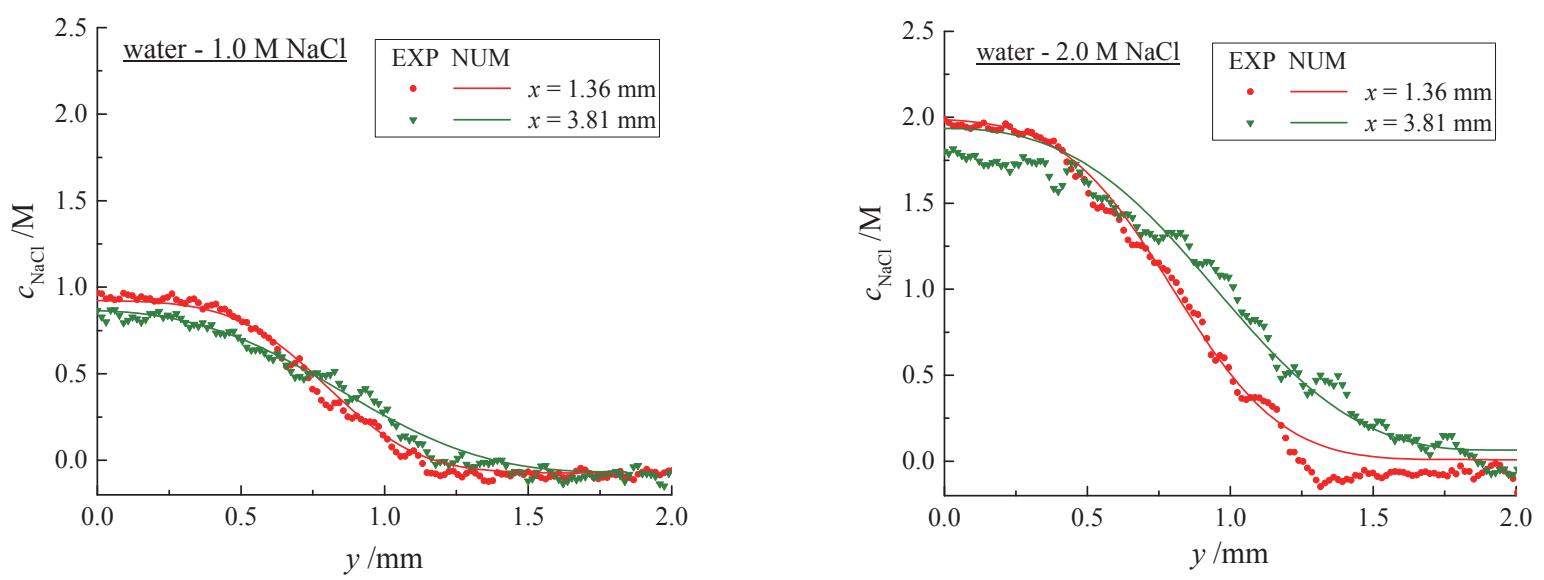

(b) Line profiles of the concentraion of $\mathrm{NaCl}$
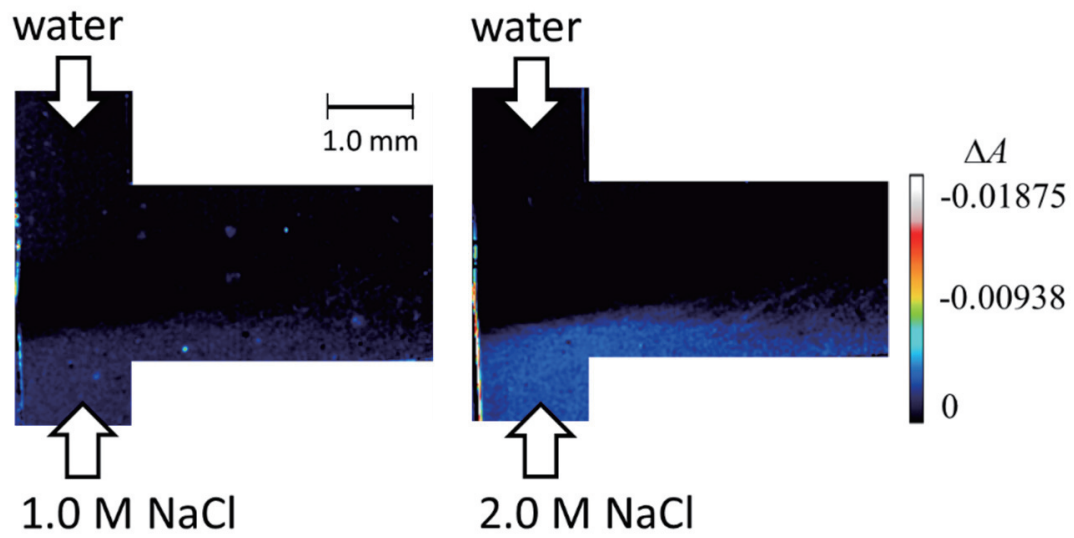

(c) Images of the absorbance difference at $1442 \mathrm{~nm}$

Fig. 5 (a) Concentration images of $\mathrm{NaCl}$ when the water and aqueous solution of $\mathrm{NaCl}$ flow in the T-shaped channel. The concentrations of the aqueous solution of $\mathrm{NaCl}$ are $1.0 \mathrm{M}$ (left) and 2.0 M (right). (b) Line profiles of the concentration of $\mathrm{NaCl}$ along the dashed lines shown in (a). (c) Images of the absorbance difference, $\Delta A$, at the wavelength of $1442 \mathrm{~nm}$ under the same conditions as in (a). 


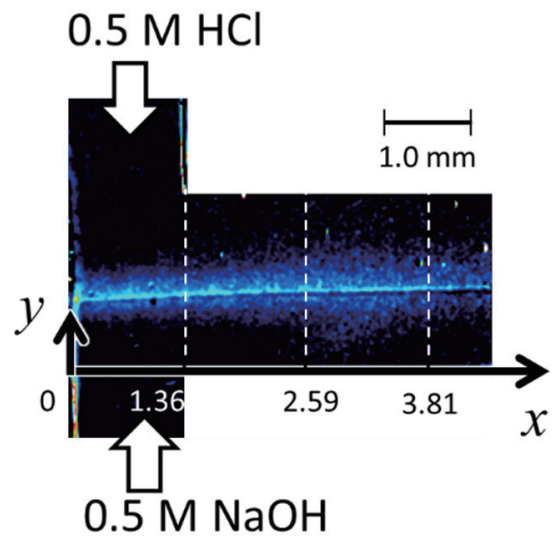

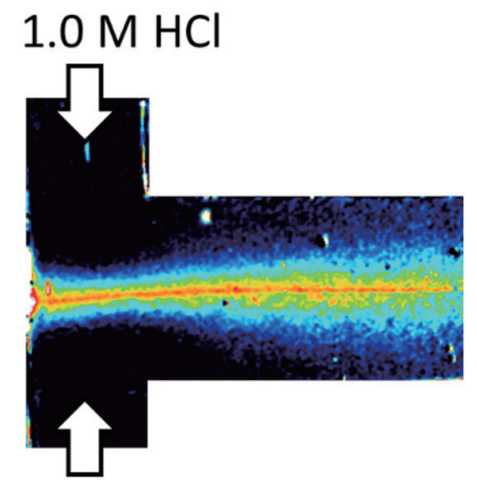

$1.0 \mathrm{M} \mathrm{NaOH}$

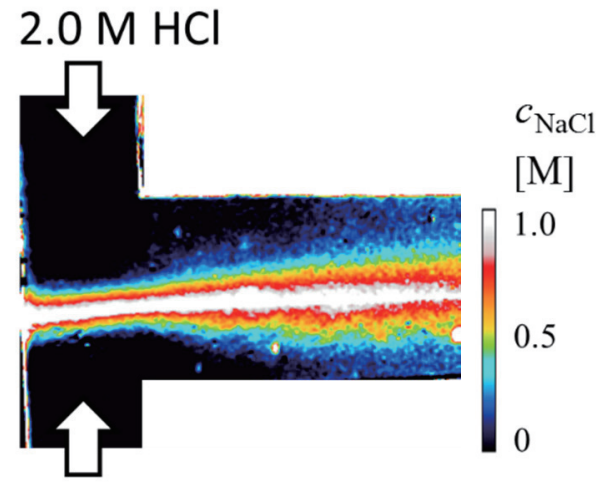

$2.0 \mathrm{M} \mathrm{NaOH}$

(a) Concentration images of $\mathrm{NaCl}$
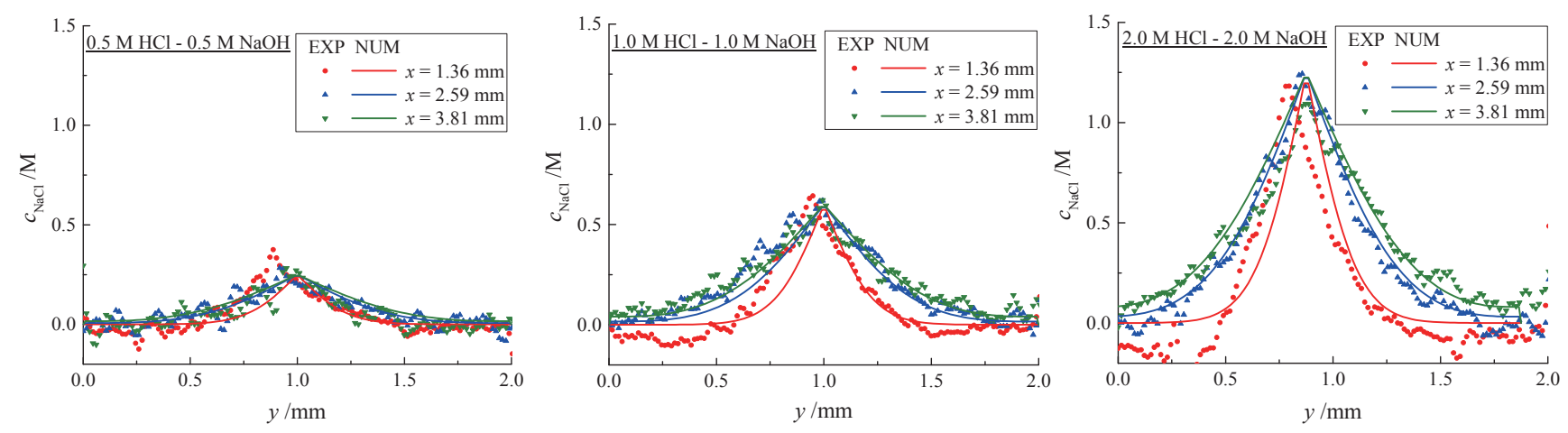

(b) Line profiles of the concentraion of $\mathrm{NaCl}$

Fig. 6 (a) Concentration images of $\mathrm{NaCl}$ when the inflows of the aqueous solutions of $\mathrm{HCl}$ and $\mathrm{NaOH}$ have the same concentrations in the T-shaped channel. The concentrations of the aqueous solutions are $0.5 \mathrm{M}$ (left image), 1.0 M (center) and 2.0 M (right). (b) Line profiles of the concentration of $\mathrm{NaCl}$ along the dashed lines shown in (a).

確認できるが, $0.5 \mathrm{M}$ の場合, 濃度のピークは検知できる ものの, 誤差のため下流方向に分布するわずかな濃度変化 は検出できていない.

Fig. 6 (b) には, 次の生成項を含む定常二次元拡散方程 式の数值解析結果も表示した.

$$
u \frac{\partial c_{\mathrm{i}}}{\partial x}+v \frac{\partial c_{\mathrm{i}}}{\partial y}= \begin{cases}D\left(\frac{\partial^{2} c_{\mathrm{i}}}{\partial x^{2}}+\frac{\partial^{2} c_{\mathrm{i}}}{\partial y^{2}}\right)-k c_{1} c_{2} & (\mathrm{i}=1,2) \\ D\left(\frac{\partial^{2} c_{\mathrm{i}}}{\partial x^{2}}+\frac{\partial^{2} c_{\mathrm{i}}}{\partial y^{2}}\right)+k c_{1} c_{2} & (\mathrm{i}=3)\end{cases}
$$

ここで， $k$ は反応速度定数であり, 中和反応での $k=1.4 \times$ $10^{11} \mathrm{M}^{-1} \mathrm{~s}^{-1}$ を採用した。 $\mathrm{i}$ は化学種 $(1: \mathrm{HCl}, 2: \mathrm{NaOH}, 3: \mathrm{NaCl})$ を表す。流速 $u$ は前節と同じである.

流量の偏りのため, $x=1.36 \mathrm{~mm}$ では実験值とのずれが 見受けられるが, 概ね一致した。特に, 実験值と数值解と もに流路中央 $(y \sim 1.0 \mathrm{~mm})$ の $c_{\mathrm{NaCl}}$ は $x$ の位置によらずほ ぼ一定值を示した。つまり, $\mathrm{NaCl}$ の周囲への拡散が生成と 釣り合っており, $k$ が非常に大きいため, 反応は拡散律速 として進行していることを示唆している. その領域に供給
される $\mathrm{HCl}$ と $\mathrm{NaOH}$ についても相互拡散により $\mathrm{NaCl}$ と同 程度の拡散輸送量となるため, そのような釣り合いが成り 立つと考えられる。

また, 流路中央の $c_{\mathrm{NaCl}}$ は, 設定された $\mathrm{HCl}$ と $\mathrm{NaOH}$ 濃 度のおよそ半分の值を示した。 これは化学量論的に生成塩 のモル数は反応物のそれと等しいが, 体積が 2 倍になるた めである.このとき同時に $\mathrm{H}_{2} \mathrm{O}$ も生成するが, 溶媒として の水が元々多量に存在するため, 体積変化はおよそ $2 \%$ と 小さく，濃度への影響はほとんどない。

$\mathrm{HCl}$ または $\mathrm{NaOH}$ のみが存在すると考えられる流路中 央から離れた領域では， $c_{\mathrm{NaCl}}$ はほぼ 0 を示した。しかし， $x=1.36 \mathrm{~mm}$ ではわずかながら負值を示した.この原因は, Fig. 3 に示されるように等吸収点においても酸・アルカリ 水溶液の影響を完全に排除できないことにある.ただし, $c_{\mathrm{NaCl}}$ の 0 からのずれは, 最大でも $2.0 \mathrm{M}$ の $\mathrm{HCl}$ と $\mathrm{NaOH}$ の ときの土 $0.1 \mathrm{M}$ 程度であり，特に，注目する界面付近では $\mathrm{HCl}$ と $\mathrm{NaOH}$ 濃度が低いため, 無視できるほど小さくな る. 


\section{5. 結論}

マイクロ流路内の中和反応により生成される塩濃度の 可視化手法を提案した. 本手法は波長 $1520 \mathrm{~nm}$ の吸光度画 像から塩濃度画像を構成寸るもので, 簡便で高速なイメー ジングを実現する. 波長 $1520 \mathrm{~nm}$ は水の $v_{1}+v_{3}$ 吸収バンド 内に存在し, その吸光度は塩濃度に対して大きく変化する 一方で, 酸・アルカリ濃度に対しては変化しないという特 性に基づき選定された。本手法による生成塩濃度の可視・ 定量性について，以下の $2 つ の$ 実験により評価した.

（1）水と $\mathrm{NaCl}$ を $\mathrm{T}$ 字型マイクロ流路内で合流させたと きの $\mathrm{NaCl}$ 濃 度 $\left(c_{\mathrm{NaCl}}\right)$ の画像を取得した. 流路内で形成 される両液間の $c_{\mathrm{NaCl}}$ の明瞭な違いと, 拡散による濃度勾 配の変化を確認した. また, $c_{\mathrm{NaCl}}$ は調整した濃度值とよく 一致した。これらの実験結果より提案手法の定量性を確認 した.

(2) 同流路を用いて, $\mathrm{HCl}$ と $\mathrm{NaOH}$ の中和反応によって 生成する $c_{\mathrm{NaCl}}$ を画像化した. 流れ方向に形成される両液間 の界面で $c_{\mathrm{NaCl}}$ が最も大きく，その分布は下流ほど拡がる 様子が確認できた。界面での $c_{\mathrm{NaCl}}$ は常に一定值を示し, 拡散による周囲からの酸・アルカリの供給と塩生成がおよ そつり合っていることが示唆された. また, その值は反応 溶液の濃度の $1 / 2$ となり, 化学量論的にも妥当な結果とな った.

最後に, 本手法では単一波長を用いたが, 複数のフィル 夕などを利用することで多波長化が容易であり, 複数成分 濃度の同時測定や温度測定に拡張できることを付記して おく，このとき，塩に関わる反応系であれば，多変量の測 定において本論文で提案した等吸収点は欠かせない. また, 他の反応系であっても同様の等吸収点の存在が確認でき れば，有効な単一波長の測定法が提案できると思われる.

\section{参 考 文 献}

1) Hartman, R.L., Jensen, K.F.: Microchemical systems for continuous-flow synthesis, Lab on a Chip - Miniaturisation for Chemistry and Biology, Vol. 9, Issue 17 (2009) pp. 2495-2507.

2) Kopp, M.U., De Mello, A.J., Manz, A.: Chemical Amplification: Continuous-Flow PCR on a Chip, Science, Vol. 280, Issue 5366 (1998) pp. 1046-1048.

3) Zhang, H., Liu, D., Shahbazi, M.-A., Mäkilä, E., Herranz-Blanco, B., Salonen, J., Hirvonen, J., Santos, H.A.: Fabrication of a Multifunctional Nano-in-micro Drug Delivery Platform by Microfluidic Templated Encapsulation of Porous Silicon in Polymer Matrix, Advanced Materials, Vol. 26, Issue 26 (2014) pp. 4497-4503.

4) Kim, H., Min, K.-I., Inoue, K., Im, D.J., Kim, D.-P., Yoshida, J.-I.: Submillisecond organic synthesis: Outpacing Fries rearrangement through microfluidic rapid mixing, Science, Vol. 352, Issue 6286 (2016) pp. 691-694.

5) Kuswandi, B., Nuriman, Huskens, J., Verboom, W.: Optical sensing systems for microfluidic devices: A review, Analytica chimica acta, Vol. 601, Issue 2 (2007) pp. 141-155.

6) Natrajan, V.K., Christensen, K.T.: Two-color laser-induced fluorescent thermometry for microfluidic systems, Measurement Science and Technology, Vol. 20, Issue 1 (2009) 015401.

7) Shinohara, K., Sugii, Y., Hibara, A., Tokeshi, M., Kitamori, T., Okamoto, K.: Rapid proton diffusion in microfluidic devices by means of micro-LIF technique, Experiments in Fluids, Vol. 38, Issue 1 (2005) pp. 117-122.

8）佐伯壮一，兼田幹也，秋元宏之，斉藤俊，西田輝夫，中村和 行：２色 LIF 法を用いたマイクロチャネル流れにおけるスカ ラー量分布計測, 可視化情報学会誌, Vol. 25, No.1 (2005) pp. 301-304.

9) Hoffmann, M., Schluter, M., Rabiger, N.: Experimental investigation of liquid-liquid mixing in T-shaped micro-mixers using $\mu$-LIF and $\mu$-PIV, Chemical Engineering Science, Vol. 61, Issue 9 (2006) pp.2968-2976.

10) Torres, J.F., Komiya, A., Shoji, E., Okajima, J., Maruyama, S.: Development of phase-shifting interferometry for measurement of isothermal diffusion coefficients in binary solutions, Optics and Lasers in Engineering, Vol. 50, Issue 9 (2012) pp.1287-1296.

11) Salmon, J.-B., Ajdań, A., Tabeling, P., Servant, L., Talaga, D., Joanicot, M.: In situ Raman imaging of interdiffusion in a microchannel, Applied Physics Letters, Vol. 86, Issue 9 (2005) pp. $1-3$.

12) Noguchi, T., Kuriyama, R., Ozawa, K., Sato, Y.: Cars microscopic measurement of multiple ion concentration in a chemical reaction, Proceedings of 17th International Conference on Miniaturized Systems for Chemistry and Life Sciences, MicroTAS 2013, Vol. 2 (2013) pp. 913-915.

13) Kakuta, N., Kondo, K., Ozaki, A., Arimoto, H., Yamada, Y.: Temperature imaging of sub-millimeter-thick water using a nearinfrared camera, International Journal of Heat and Mass Transfer, Vol. 52, Issue 19-20 (2009) pp. 4221-4228.

14) Manley, M.: Near-infrared spectroscopy and hyperspectral imaging: Non-destructive analysis of biological materials, Chemical Society Reviews, Vol. 43, Issue 24 (2014) pp. 8200-8214.

15) Kakuta, N., Arimoto, H., Kondo, K., Kawashima, D., Yamada, Y.: Simultaneous imaging of temperature and concentration of aqueous solutions using the near-infrared absorption characteristics of water, Proceedings of the ASME 2013 11th International Conference on Nanochannels, Microchannels, and Minichannels (2013) ICNMM2013-73155.

16) Kawashima, D., Kakuta, N., Kondo, K., Arimoto, H., Yamada, Y. Visualization and analysis of heat and mass transfer with chemical reactions in microchannels, Proceedings of the 15th International Heat Transfer Conference IHTC-15, IHTC15-9380 (2014).

17) Kawashima, D., Kakuta, N., Arimoto, H., Kondo, K., Yamada, Y.: Near-infrared multi-wavelength imaging to elucidate ionic diffusion and reaction in aqueous solutions, Proceedings 5th Asian Pacific-Rim Symposium on Biophotonics, APBP7-5 (2015).

18）川嶋大介, 角田直人, 近藤克哉, 有本英伸, 山田幸生 : 近赤 外域の 2 波長同時イメージング法を利用したマイクロ流路内 の発熱反応の可視化, 日本機械学会熱工学コンファレンス 2014 講演論文集 (2014), D142.

19）川嶋大介, 角田直人, 有本英伸, 近藤克哉, 山田幸生 : 近赤 外吸収分光法を利用した中和反応生成物の可視化，第 43 回 可視化情報シンポジウム講演論文集 (2015), E108.

20）川嶋大介, 角田直人, 近藤克哉, 有本英伸, 山田幸生 : 近赤 
外吸収イメージング法を用いた中和反応界面近傍の濃度の 計測, 日本機械学会熱工学コンファレンス 2015 講演論文集 (2015), G221.

21) 岩本令吉 : 近赤外スペクトル法, 講談社 (2008).

22) Šašić, S., Segtnan, V.H., Ozaki, Y., Self-modeling curve resolution study of temperature-dependent near-infrared spectra of water and the investigation of water structure, Journal of Physical Chemistry A, Vol. 106, Issue 5 (2002) pp. 760-766.

23) Czarnik-Matusewicz, B., Pilorz, S., Hawranek, J.P.: Temperaturedependent water structural transitions examined by near-IR and mid-IR spectra analyzed by multivariate curve resolution and twodimensional correlation spectroscopy, Analytica Chimica Acta Vol. 544, Issue 1-2, (2005) pp. 15-25.

24) Grant, A., Davies, A.M.C., Bilverstone, T.: Simultaneous determination of sodium hydroxide, sodium carbonate and sodium chloride concentrations in aqueous solutions by near-infrared spectrometry, The Analyst (1989) Vol. 114, pp. 819-822.

25) Frank, H.S., Wen, W.: Ion-solvent interaction. Structural aspects of ion-solvent interaction in aqueous solutions: A suggested picture of water structure (1957) Vol. 24, pp. 133-140

26) Libnau, F. O., Kvalheim, O. M., Christy, A. A. and Toft, J.: Spectra of water in the near- and mid-infrared region, Vib. Spectrosc. Vol. 7 (1994) pp. 243-54.

27) Czarnik-Matusewicz B. and Pilorz S.: Study of the temperaturedependent near-infrared spectra of water by two-dimensional correlation spectroscopy and principal components analysis, Vib. Spectrosc. Vol. 40 (2006) pp. 235-45.

28) Kirby, B. J.: Micro- and Nanoscale Fluid Mechanics, Cambridge University Press (2010) pp. 82-84.

29) Lemaigre, L., Budroni, M.A., Riolfo, L.A., Grosfils, P., De Wit, A.: Asymmetric Rayleigh-Taylor and double-diffusive fingers in reactive systems, Physics of Fluids, Vol. 25 (2013) 014103.

30) Kakuta, N., Yamashita, H., Kawashima, D., Arimoto, H., Kondo, K., Kawashima, D., Yamada, Y.: Simultaneous imaging of temperature and concentration of ethanol-water mixtures in microchannel using near-infrared dualwavelength absorption technique, Meas. Sci. Technol. Vol. 27 (2016) 115. 